\title{
Solar urticaria
}

INSERM

\section{Source}

INSERM. (1999). Orphanet: an online rare disease and orphan drug data base. Solar urticaria. ORPHA:97230

Solar urticaria (SU) is a rare and difficult to treat photosensitive disease, in which local skin swelling occurs within minutes of exposure to natural sunlight or even artificial light sources emitting ultraviolet radiation. 